\title{
Choice of Information Learning: Evidence from Revisiting Price Discovery during the 2006 Dual Listing Craze in China
}

\author{
Yingchao Zhang1, Xiang Gao ${ }^{2}$, Shuzhen $\mathrm{Niu}^{3 *}$ \\ ${ }^{1}$ Business School, Durham University, Durham, UK \\ ${ }^{2}$ Research Center of Finance, Shanghai Business School, Shanghai, China \\ ${ }^{3}$ School of Business, Sanda University, Shanghai, China \\ Email: *nsz66@sina.com
}

How to cite this paper: Zhang, Y. C., Gao, X., \& Niu, S. Z. (2021). Choice of Information Learning: Evidence from Revisiting Price Discovery during the 2006 Dual Listing Craze in China. Theoretical Economics Letters, 11, 1165-1182.

https://doi.org/10.4236/tel.2021.116074

Received: October 23, 2021

Accepted: December 6, 2021

Published: December 9, 2021

Copyright $\odot 2021$ by author(s) and Scientific Research Publishing Inc. This work is licensed under the Creative Commons Attribution International License (CC BY 4.0).

http://creativecommons.org/licenses/by/4.0/

\begin{abstract}
Extant studies have proposed information choice models to explain the home bias puzzle. In this paper, we explore information asymmetries among local and non-local investors which are captured by market microstructure variables to explain the repercussions of their information choices. We examine the short-run price dynamics, co-integrating relations, and price discovery processes of cross-listed Chinese firms. Using high-frequency data over the year 2006 of dual listing craze in history, we find that the local A-share market contributes to the price discovery for $68 \%$ to $75 \%$ of the firms, which is far more than the contribution of the non-local $\mathrm{H}$-share market. Our results support the learning choice model and suggest that local Chinese investors may be endowed with a small home information advantage and their learning choices magnify information asymmetry. As such, the local stock market incorporates new information faster and contributes more to the price discovery of dual-listed firms in mainland China.
\end{abstract}

\section{Keywords}

Learning Choice, Home Bias, Price Discovery, Asymmetric Information

\section{Introduction}

Why do investors overinvest in domestic stocks? Researchers extensively study the determinants of home bias, including turnover (Tesar \& Werner, 1995), transaction costs (Glassman \& Riddick, 2001), corporate governance (Dahlquist et al., 2003), information costs (Ahearne et al., 2004), and the real exchange rate 
risks (Fidora et al., 2007) of foreign assets versus those of domestic assets ${ }^{1}$. Recently, Nieuwerburgh \& Veldkamp (2009) use an information choice model to show that learning choice is one factor that causes home bias. In this paper, we apply the information share model of Hasbrouck (1995) to explore how information is incorporated into the prices of dual-listed firms. An overinvestment in domestic stocks, which is characterized by a high percentage of domestic assets over the total market capitalization, suggests that investors may have forgone the potential benefits of international diversification. Even after taking transaction costs into account, Li et al. (2003) show that the diversification benefit is substantial. The evidence against an international portfolio theory creates the home bias puzzle. Is this bias a result of a concentrated ownership structure? Most companies in emerging markets are family-owned or closely-held, and controlling shareholders may enjoy the significant private benefits of control and may be reluctant to sell their shares; however, Dahlquist et al. (2003) use a world float portfolio to adjust for concentrated ownership structures, and they show that a home bias still prevails.

Prior studies argue that home bias could be caused by a prior information advantage. A counter-argument to this explanation is that information asymmetry and, consequently, home bias could be eliminated when investors can learn (Nieuwerburgh \& Veldkamp, 2009). However, in some countries, such as China, citizens can only invest in their own country's stock markets, and only after 2006 have channels been created to allow them to invest overseas. Restrictions that Chinese investors face in their local stock market lower their opportunity costs for acquiring costly information of local firms that are listed on China's stock markets. This creates a comparative advantage for Chinese investors in obtaining information about local firms, which amplifies the information asymmetry. Chinese mainland investors have no learning choice, in contrast to non-local investors outside mainland China, who possess an abundance of learning choices. Because information learning is costly, it is plausible that non-local investors would choose to free-ride on local investors' information about Chinese stocks (and profit in non-local stock markets) because of 1) the non-local investors' initial information disadvantage and 2) the magnification of the repercussions of this comparative information disadvantage by local institutional features ${ }^{2}$. As Nieuwerburgh and Veldkamp (2009) suggest, home investors are more likely to have a higher learning index in comparison to non-local investors. Therefore, Chinese investors who are investing in local stock markets should learn more than non-local investors in non-local stock markets for dual-listed firms, thus amplifying the Chinese investors' information advantage. We, therefore, expect that the price discovery, which we investigate via the information share model, should primarily be driven by the local stock markets.

${ }^{1}$ See Demirgüç-Kunt and Huizinga (1995), Noronha et al. (1996), and follow-up studies on approaching the home bias puzzle.

${ }^{2}$ Our argument also alludes to the ramifications of information market creation, as modeled by Veldkamp (2006). 
This paper explores the process of how information is incorporated into prices for each pair of 17 firms that has one legal entity traded in the A-share market of the Shanghai Stock Exchange (SSE) and the other traded in the H-share market of the Hong Kong Stock Exchange (HKEx) during the 2006 craze of dual listing. By employing the information share model (Hasbrouck, 1995), we find that, in both statistical and economic terms, the A-shares of SSE firms play a more dominant role in the price discovery than the H-shares of the Hong Kong market. The A-shares contribute $68 \%$ to $75 \%$ of the price discovery, whereas the $\mathrm{H}$-shares of HKEx firms contributed only $2 \%$ to $11 \%$. Our findings support the learning choice hypothesis (Nieuwerburgh \& Veldkamp, 2009) in that home investors, on average, choose to learn more about and buy more home assets, whereas non-local investors restrain from competing in the information market. As such, mainland stock markets incorporate new information faster and markedly contribute to price discovery. We find consistent results for each month of the year in our sample, which suggests that our major result is not driven by a seasonality effect, such as the January effect.

The local market dominance of price discovery may be due to infrequent trading of stocks or differences in trading mechanisms. This unique setup of $\mathrm{A}-\mathrm{H}$ stock markets enables us to analyze local and non-local investors while controlling for firm fundamentals and microstructure differences. Our findings of the dominance of the local market in the contribution of price discovery cannot be driven by non-synchronous trading as the trade size and turnover in both markets are similar. Also, the local market dominance is not driven by the heterogeneity of trading mechanisms because both exchanges are pure order-driven markets.

The novelty of this paper is twofold. One contribution is that we show that the local market dominates the price discovery process in 2006 during China's stock market boom period. We examine several explanations for the home bias puzzle during the period from January 2006 to December 2006, when China's stock market experienced a dramatic price appreciation. First, this boom period would serve as a natural field experiment setting for understanding the investors learning choices. Second, we describe how quickly information flows between different markets during this boom period. Third, our results show that the home investors move first, and their behavior influences the non-local investors. Our findings not only help with explaining the home bias puzzle but also have important implications for portfolio diversifications among $\mathrm{A}$ and $\mathrm{H}$ shares. This information-based model helps to enhance the understanding of the phenomenon and loosen the international capital flow constraints. The investors could learn both domestic and non-local information. The non-domestic inventors could learn information from home investors as well.

The other novelty of our paper lies in explaining the home bias puzzle by investigating learning choice in two of the largest order-driven emerging markets with dual-listed firms. We contribute to the price discovery and the learning choice literature as follows. First, we are among the first to investigate the price discovery from the historical and theoretical perspective in two of the largest 
order-driven emerging markets with dual-listed firms. Second, our analysis of the $\mathrm{A}$ - and $\mathrm{H}$-share markets demonstrates that local investors dominate the price discovery of these dual-listed firms. Third, we provide direct evidence of the ability of local investors in exploiting local information by measuring their contribution to price discovery while previous studies focus on their portfolio returns. Fourth, we uncover the unobservable learning choice of investors through price discovery. Our results describe how quickly information could flow from the local market to the non-local market, and how trading behaviors of local investors causally affect non-local investors. Hence, the home bias can be explained by learning choice.

The rest of the paper is organized as follows. Section 2 reviews the related literature. Section 3 describes the institutional background and data. Section 4 explains the empirical framework. Our results are presented in Section 5. Section 6 concludes the paper.

\section{Price Discovery and Information Choice}

Home bias models are based on international capital flow constraints when this strand of literature initiates. But, as the capital flow constraints decrease among countries, the home bias persists, thus information-based models are used to explain the phenomenon. These models usually assume that information is not flowing freely across markets; hence, investors may choose to learn only information about their own country's stocks. Nieuwerburgh and Veldkamp (2009) develop an information choice model to predict how investors choose to learn about domestic and non-local information. They demonstrate that home investors optimally choose to learn domestic information even if they can learn non-local information. This is because home investors have a comparative advantage in collecting domestic information. If two different investors have their initial information advantage, the information asymmetry between the local investor and the non-local investor would be further magnified because of the comparative advantage of the former in collecting information. If the information share of domestic shareholders is substantially higher than that of non-local investors, the non-local investors will choose not to learn the domestic information; therefore, our results would support this learning choice model.

However, international finance theories provide inconclusive evidence of why individuals tilt their portfolios toward local stocks. Grinblatt and Keloharju (2000) show that foreign investors in these markets can earn abnormal profits and seem to be more informed. Recently, Seasholes and Zhu (2010) find that local investors do not generate abnormal returns, therefore implying that there is no information advantage for domestic investors when they trade. Ivković and Weisbenner (2005) find that individual households can exploit locally available, non-public information to earn excess returns. Massa and Simonov (2006) document evidence that investors tilt their portfolio towards stocks that are most closely related to them including local stocks and conclude that information is 
driving these decisions. During our sample period (January 2006 to December 2006), because of Mainland China's capital flow restrictions, local investors in China could not invest in the $\mathrm{H}$-share market traded at the HKEx. According to the temporary regulations on Chinese domestic investment during that period, only a few large foreign financial institutions were able to invest in China through the Qualified Foreign Institutional Investor program. During this period, foreign investors could invest in $\mathrm{H}$-shares freely. Therefore, if foreign institutions are better informed, we should observe an even distribution of the information shared between the two markets.

Many studies investigate cross-border listings and price discovery in U.S. equity markets, such as Hasbrouck (1995), Smith and Sofianos (1997), and Eun and Sabherwal (2003), Stoll and Whaley (1990) and Chan (1992) examine the causal relationships between financial markets to analyze price discovery ${ }^{3}$. The price discovery of cross-border listings has yet to be fully explored, however, because of differences in the institutional settings of exchanges in various regions, such as the trading hours, exchange rate differentials, transaction costs, and price limits of individual markets. Examining cross-border listed companies in the Hong Kong and mainland stock markets mitigates most of the above differences. While many researchers study causal relations and price discovery processes in developed markets, such as the New York Stock Exchange (NYSE), relatively few studies are devoted to emerging markets. Chui and Kwok (1998) and Chan et al. (2008) both examine the correlation between the local A-share and foreign B-share markets. Wong et al. (2009) study the informed trading and liquidity in the SSE. The unique institutional setting in Chinese stock markets-A-share, B-share, and $\mathrm{H}$-share markets-provides a natural setting to research the price information for single security with several prices. ${ }^{4}$. In particular, we focus on Chinese A-share and $\mathrm{H}$-share markets because the B-share market has a particularly low liquidity relative to its $\mathrm{A}$ - and $\mathrm{H}$-share counterparts.

\section{Sample Data and Institutional Background}

At the sample period year of 2006, there were 1,421 and 1,165 firms traded in the A-share and $\mathrm{H}$-share market, respectively. Our sample comprises $17 \mathrm{~A}-\mathrm{H}$ dual-listed state-owned enterprises (SOEs) that maintain close and strong relationships to the Chinese government. Although they only account for $1 \%$ of total firm number in each market, these 17 large-cap stocks match the requirement made by Nieuwerburgh and Veldkamp (2009) in their theoretical model that local investors are endowed with an initial information advantage. Since SOEs operations are mainly in China, we expect that local Chinese investors may have an

${ }^{3}$ Mech (1993) and Hameed (1997) argue that stock price information on the reaction rate difference is the fundamental reason for the lead-lag relationships.

${ }^{4} \mathrm{~A}-$, B-, and H-shares are three types of shares that are issued by Chinese firms. Trading A-shares is restricted to domestic investors. B-shares can only be traded by foreign investors in February 2001. Offshore stocks that are listed and traded in the HKEx but issued by companies that operate and have headquarters in mainland China are H-shares. 
information advantage over foreign investors. The high-frequency data that are used in this study are obtained from two sources. The high-frequency transactions prices, transaction volumes, and quotes of A-share firms are obtained from the CSMAR high-frequency database, which contains all of the stock trades and quote updates for each trading day, sorted by symbol and stamp time. We directly obtained the intra-day trade and quote records of China $\mathrm{H}$-shares from the HKEx. The trade record is a collection of data files that contain intra-day trade information recorded by the exchange. The quote record is a collection of data files that contain intra-day quote information for both the bid and ask sides of the market recorded by the exchange.

There are two unique advantages of studying dual-listed firms in mainland China and Hong Kong. First, both types of shares are substantially traded in their markets, and they have a long period of simultaneous trading hours ${ }^{5}$. Second, both Hong Kong's and China's stock markets are order-driven markets, i.e., markets without designated market makers to provide liquidity. This enables us to compare our results with previous studies from specialist markets, such as the NYSE. This also creates a unique opportunity to investigate the short-run price dynamics, co-integrating relations, and price discovery processes of cross-listed firms based on Hasbrouck's (1995) information share theory.

The sample period that is considered here ranges from January $1^{\text {st }}, 2006$ to December $31^{\text {st }}$, 2006. To avoid the infrequent trading problem and non-synchronous trading problems, we included firms in the Hang Seng China AH Premium Index, which includes the largest and most liquid Mainland China companies with both A- and $\mathrm{H}$-share listings ${ }^{6}$. This Premium Index comprises firms that have A-shares that are listed on the SSE or the Shenzhen Stock Exchange (SZSE) and $\mathrm{H}$-shares that are listed on the Main Board of the HKEx ${ }^{7}$. In December 2006, 24 companies were listed on the Premium Index. Because of additions and deletions in the Premium Index of constituent stocks, our final sample consists of 17 firm pairs that are listed on both SSE/SZSE and the HKEx. The reason we choose the year 2006 is because of two historical events. First, the Industrial and Commercial Bank of China had by that time the largest initial public offering on the above-mentioned two exchanges in 2006, which created a craze for speculation on dual listing. Second, the AH Premium Index can be backdated to January 2006 and its official launch date is July $9^{\text {th }}, 2007$. As a result, the information

${ }^{5}$ These are two perfectly segmented markets, yet their pricing schemes would be different, as indicated by the A-H share index premium, which indicates that the A-share prices, on average, have a significant premium over shares of the same stock that are listed on the Hong Kong H-share stock market; however, the two price series are co-integrated.

${ }^{6}$ See the selection criteria of the Hang Seng China AH Premium Index description in the Hang Seng Indices Company Limited, http://www.hsi.com.hk/HSI-Net/HSI-Net.

${ }^{7}$ The second board, Growth Enterprise Market, does not require growth companies to have achieved a record of profitability as a condition of listing. The future performance of growth companies particularly those without a profit track record are susceptible to great uncertainty. Because of the higher risks involved, GEM is designed for professional and informed investors. It works on the basis of caveat emptor or buyers beware. See the HKEx GEM website,

http://www.hkgem.com/aboutgem/e_default.htm. 
learning behaviors during the year 2006 are more market-oriented during this test running period. As our focus lies on informed investment decisions made by market participants, high-frequency transactions, which aim at exploiting mispricing across the A-shares and H-shares market in 2006 for the same underlying firm, provide a good laboratory to study our hypothesis of price discovery based on information learning.

Table 1 reports the summary statistics for the key variables we use in the subsequent analysis from January $1^{\text {st }}, 2006$ to December $31^{\text {st }}, 2006$. The A-H share premium index includes 17 firms, dual-listed on both SSE/SZSE and the HKEx in 2006, and there are a total of 2,156,373 transaction records for the two price series during this period.

\section{Methodology}

\subsection{Forming the Synchronized Price Series for A- and H-Shares}

While Hong Kong and mainland China are in the same time zone, the trading hours for the SSE/SZSE and HKEx are different. The SSE/SZSE have regular trading hours that range from 9:30 am to $11: 30 \mathrm{am}$ and from 1:00 pm to 3:00 pm, whereas the HKEx has trading hours of 10:00 am to 12:30 pm and 2:30 pm to $3: 55 \mathrm{pm}$. Therefore, the common regular trading hours for both are 10:00 am to $11: 30 \mathrm{am}$ and $2: 30 \mathrm{pm}$ to $3: 00 \mathrm{pm}$. We included only the transaction records for the trading hours between 10:05 am and 11:25 am in the morning session and between 2:35 pm and 2:55 pm in the afternoon session because these are the common trading hours. Stoll and Whaley (1990) argue that the opening transaction in higher volume stocks is likely to reflect an opening auction of trading. For this reason, Chan et al. (2008) delete the first and last 15 minutes in both the morning and afternoon sessions. Likewise, in our sample, we excluded the first and last 5 minutes in both the morning and afternoon sessions and paired the remaining trades in the common trading hours (10:05 am to 11:25 am in the morning session and 2:35 pm to 2:55 pm in the afternoon session). For each stock, we form the two price series using the minimal span procedure, as described in Harris (1995). That is, we form synchronous pairs of transaction prices for each stock sample between 10:05:00 and 11:25:00 and between 14:35:00 and 14:55:00. The advantage of this method is that it matches trades that are closest by time, which better represents the paired series than using a fixed time interval. We normalize the two price series for each firm in the same currency (RMB). We convert the Hong Kong dollar (HKD) to RMB.

The average exchange rate during the data sample period of 2006 for HKD to $\mathrm{RMB}$ is 0.96 to 1 , according to the records of financial data from the Bank of China $^{8}$. For our sample, there are a total of 1,449,222 trades for A-shares and 707,151 trades for $\mathrm{H}$-shares, which add to a total of 2,156,373 trades. The final sample contains 17 pairs of A-share and $\mathrm{H}$-share price series of dual-listed firms with 199 firm-month observations and 320,274 paired trades. Table 2 reports ${ }^{8}$ See http://www.bankofchina.com. 
Table 1. Summary statistics.

\begin{tabular}{|c|c|c|c|c|c|c|}
\hline \multirow{2}{*}{ Company Name } & \multicolumn{2}{|c|}{ Stock Code } & \multicolumn{2}{|c|}{ Daily Trades } & \multicolumn{2}{|c|}{ Trade Size (1) } \\
\hline & A-Share & H-Share & A-Share & H-Share & A-Share & H-Share \\
\hline HUANENG POWER & $\mathrm{CH} 600011$ & HK902 & 1161 & 745 & 11,101 & 33,101 \\
\hline ANHUI EXPRESS WAY & $\mathrm{CH} 600012$ & HK995 & 855 & 123 & 8577 & 17,587 \\
\hline CHINA SHIP DEV & $\mathrm{CH} 600026$ & HK1138 & 1580 & 490 & 10,330 & 21,028 \\
\hline HUADIAN POWER & $\mathrm{CH} 600027$ & HK1071 & 1223 & 309 & 11,215 & 27,833 \\
\hline SINOPEC CORP & $\mathrm{CH} 600028$ & HK386 & 1817 & 2097 & 26,765 & 57,518 \\
\hline CHINA SOUTH AIR & $\mathrm{CH} 600029$ & HK1055 & 1392 & 458 & 20,183 & 22,797 \\
\hline YANZHOU COAL & CH600188 & HK1171 & 1349 & 840 & 8898 & 29,147 \\
\hline GUANGZHOU PHAR & $\mathrm{CH} 600332$ & HK874 & 657 & 55 & 4004 & 18,039 \\
\hline JIANGXI COPPER & $\mathrm{CH} 600362$ & HK358 & 1613 & 1800 & 7640 & 17,682 \\
\hline JIANGSU EXPRESS & $\mathrm{CH} 600377$ & HK177 & 661 & 351 & 4855 & 22,762 \\
\hline SHENZHEN EXPRESS & $\mathrm{CH} 600548$ & HK548 & 639 & 171 & 7914 & 20,139 \\
\hline ANHUI CONCH & $\mathrm{CH} 600585$ & HК914 & 515 & 237 & 5132 & 10,038 \\
\hline TSINGTAO BREW & $\mathrm{CH} 600600$ & HK168 & 967 & 146 & 5495 & 8278 \\
\hline GUANGZHOU SHIP & $\mathrm{CH} 600685$ & HK317 & 1111 & 169 & 5324 & 11,588 \\
\hline MAANSHAN IRON & $\mathrm{CH} 600808$ & HK323 & 1330 & 888 & 15,637 & 35,519 \\
\hline TIANJIN CAPITAL & $\mathrm{CH} 600874$ & HK1065 & 870 & 141 & 5255 & 20,783 \\
\hline DONGFANG ELEC & $\mathrm{CH} 600875$ & HK1072 & 741 & 204 & 2697 & 7883 \\
\hline \multirow[t]{3}{*}{ Total } & & & 18,481 & 9224 & 161,022 & 381,722 \\
\hline & \multicolumn{2}{|c|}{ Trade Size (2) } & \multicolumn{2}{|c|}{ Daily Volume } & \multicolumn{2}{|c|}{ Daily Turnover } \\
\hline & A-Share & H-Share & A-Share & H-Share & A-Share & H-Share \\
\hline HUANENG POWER & 74,057 & 183,827 & $12,887,995$ & $24,669,440$ & $85,976,285$ & $137,000,606$ \\
\hline ANHUI EXPRESS WAY & 47,089 & 92,510 & $7,336,428$ & $2,161,869$ & $40,278,514$ & $11,372,047$ \\
\hline CHINA SHIP DEV & 80,384 & 141,835 & $16,318,731$ & $10,305,395$ & $126,981,993$ & $69,510,583$ \\
\hline HUADIAN POWER & 39,293 & 64,216 & $13,711,005$ & $8,605,301$ & $48,037,659$ & $19,853,951$ \\
\hline SINOPEC CORP & 232,763 & 283,055 & $48,643,641$ & 120602168 & $423,029,267$ & $593,504,453$ \\
\hline CHINA SOUTH AIR & 65,634 & 55,489 & $28,089,812$ & 10429999 & $91,347,077$ & $25,387,203$ \\
\hline YANZHOU COAL & 59,554 & 171,630 & $12,004,926$ & $24,472,030$ & $80,351,396$ & $144,099,680$ \\
\hline GUANGZHOU PHAR & 34,462 & 78,733 & $2,629,342$ & 992,064 & $22,631,628$ & $4,329,969$ \\
\hline JIANGXI COPPER & 103,180 & 120,987 & $12,322,205$ & $31,818,811$ & $166,411,741$ & $217,717,411$ \\
\hline JIANGSU EXPRESS & 32,728 & 106,065 & $3,210,711$ & $7,996,026$ & $21,641,198$ & $37,259,233$ \\
\hline SHENZHEN EXPRESS & 33,386 & 71,280 & $5,058,557$ & $3,451,703$ & $21,339,424$ & $12,217,235$ \\
\hline ANHUI CONCH & 80,771 & 144,690 & $2,643,166$ & $2,374,980$ & $41,600,353$ & $34,233,228$ \\
\hline
\end{tabular}


Continued

\begin{tabular}{ccccccc}
\hline TSINGTAO BREW & 64,158 & 82,677 & $5,313,471$ & $1,212,256$ & $62,040,289$ & $12,107,970$ \\
GUANGZHOU SHIP & 50,366 & 66,433 & $5,917,384$ & $1,957,423$ & $55,977,250$ & $11,221,781$ \\
MAANSHAN IRON & 60,920 & 103,349 & $20,802,509$ & $31,532,233$ & $81,044,323$ & $91,748,566$ \\
TIANJIN CAPITAL & 25,284 & 43,005 & $4,572,216$ & $2,934,626$ & $21,999,508$ & $6,072,604$ \\
DONGFANG ELEC & 52,479 & 105,338 & $1,997,587$ & $1,609,641$ & $38,868,468$ & $21,508,082$ \\
Total & $1,136,508$ & $1,915,119$ & $203,459,686$ & $287,125,965$ & $1,429,556,373$ & $1,449,144,602$ \\
\hline
\end{tabular}

Note: This table reports the summary statistics of each A-share and H-share pair of our sample firms from January $1^{\text {st }}$, 2006 to December $31^{\text {st }}$, 2006. There are 17 pairs of firms that are listed on both the SSE/SZSE and the HKEx during 2006. "Daily Trades" corresponds to the average number of trades in each day of 2006, which is equal to the total number of trades/number of trading days. "Trade Size (1)" corresponds to the trade size as measured by the number of shares and is equal to the average number of shares in each trade. "Trade Size (2)" corresponds to the trade size as measured by the turnover and is equal to the average turnover of each trade. "Daily Volume" equals the average number of shares that are traded each day. "Daily Turnover" equals the average turnover that is traded in each day.

Table 2. Co-integration test of the A- and H-shares.

\begin{tabular}{|c|c|c|c|}
\hline Month & Lags & Tau & 5\% Sig. \\
\hline Jan. & 1 & -2.7865 & $6 / 17$ \\
\hline Feb. & 1 & -2.9029 & $7 / 17$ \\
\hline Mar. & 1 & -2.7380 & $5 / 15$ \\
\hline Apr. & 1 & -3.1376 & $8 / 17$ \\
\hline May & 1 & -1.9400 & $0 / 17$ \\
\hline Jun. & 1 & -2.8518 & $7 / 17$ \\
\hline Jul. & 1 & -2.0763 & $5 / 16$ \\
\hline Aug. & 1 & -2.5582 & $7 / 17$ \\
\hline Sep. & 1 & -2.6453 & $6 / 17$ \\
\hline Oct. & 1 & -2.4419 & $5 / 16$ \\
\hline Nov. & 1 & -2.4975 & $4 / 16$ \\
\hline \multirow[t]{2}{*}{ Dec. } & 1 & -2.6235 & $6 / 17$ \\
\hline & & -2.6000 & $66 / 199$ \\
\hline
\end{tabular}

Note: This table reports the results of the co-integration tests of the A-share and H-share price series from January $1^{\text {st }}, 2006$ to December $31^{\text {st }}, 2006$. We follow Chan et al. (2007) in testing co-integration by testing the stationarity of the price differential across the A-share and $\mathrm{H}$-share prices for a stock $j$ in period $t$. We use an augmented Dickey and Fuller (1981) unit root test and the Dickey et al. (1984) limiting distribution for seasonal unit roots. The $5 \%$ left tail critical value of the unit root null hypothesis is -2.86 . For each firm-month observation, we compute the cross-sectional average of the test statistics Tau, following Chan et al. (2008). A significant Tau implies that the prices are co-integrated. The last column presents the number of tests that are significant at the $5 \%$ level out of the 16 or 17 cross-listed pairs for the month under concern. 
the results of the co-integration test of the A-share and $\mathrm{H}$-share price series from January $1^{\text {st }}, 2006$ to December $31^{\text {st }}$, 2006. We follow Chan et al. (2007) in testing the co-integration by looking at the stationarity of the price differential across the A-share price $\left(P_{j, t}^{A}\right)$ and the $\mathrm{H}$-share price $\left(P_{j, t}^{H}\right)$ for stock $j$ in period $t$, which is denoted by $y_{j, t}=P_{j, t}^{A}-P_{j, t}^{H}$. We use an augmented Dickey and Fuller (1981) unit root test and the Dickey et al. (1984) limiting distribution for seasonal unit roots.

\subsection{Information Share}

In this section, we examine the short-term dynamics of the price series in each firm-month observation regarding the co-integrating relations of the A-share and $\mathrm{H}$-share price pairs and the price discovery process using the Hasbrouck (1995) information share method. Hasbrouck (1995) breaks down the common factor variance, and new information in each market on the common factors contributes to the variance ratio to define the price discovery. The effective prices of A-shares and $\mathrm{H}$-shares are facilitated by effective information that is obtained from the two markets, and fluctuations therein are a result of newly incorporated information. The newly incorporated information may arise from the existing A-share market, from the $\mathrm{H}$-share market, or simultaneously from both markets. If it is simultaneously generated from the two markets, then the price discovery for assets of the two markets is a joint decision based on the information. When newly incorporated information of the market impacts the asset prices, the market prices of assets contribute to the price discovery. Hasbrouck (1995) identifies a positive and statistically significant correlation between the NYSE contribution to price discovery and its market share by trading volume by employing the information share model. He finds that the information share of the NYSE is around $92.7 \%$ and that the NYSE's contribution is significantly positively correlated with its trading volume market share in medium-size trades but not with shares in small or large trades. Our paper presents an econometric model of a firm that is listed in both the A-share and $\mathrm{H}$-share markets.

We employ the information share model used by Hasbrouck (1995) as the measure of the relative contribution of the $\mathrm{A}$-share price and the $\mathrm{H}$-share price to the common price discovery process. Hasbrouck's starting point is that if a security trades in two different markets, then its prices in the two markets should be co-integrated. The shared information is a nonlinear function of the VAR coefficients and the disturbance covariance matrix. Accordingly, this study adopts Hasbrouck's (1995) route of addressing the issue of statistical significance by considering cross-sectional estimates of the information share and related measures. In our study, two price variables are closely related to single security transaction prices in $\mathrm{A}$-share and $\mathrm{H}$-share markets. Assume that there are $\mathrm{n}$ price variables that are closely related to a single security, such as transaction prices in $\mathrm{n}$ markets. These variables can be collected in a $(n \times 1)$ column vector 
$p_{t}$ Each price series is assumed to be integrated of order 1 ; i.e., it contains a random walk component. The price changes are assumed to be covariance stationary. This implies that they may be expressed as the vector moving average:

$$
\Delta p_{t}=\psi(L) e_{t}
$$

where $e_{t}$ is a zero-mean vector of serially uncorrelated disturbances with a covariance matrix $\Omega$, and $\psi$ is a polynomial in the lag operator. Suppose that there exists a non-stationary autoregressive representation of order $\mathrm{k}$ for the price levels:

$$
A(L) p_{t}=k+e_{t} \text { and } A(L)=I-A_{1} L-A_{2} L-A_{k} L^{k} .
$$

Then, according to the Granger Representation Theorem, there exists an error correction model (ECM) of the following form:

$$
\Delta p_{t}=\alpha\left(\beta^{\prime} p_{t-1}-E \beta^{\prime} p_{t}\right)+\Gamma_{1} \Delta p_{t-1}+\Gamma_{2} \Delta p_{t-2}+\cdots+\Gamma_{k-1} \Delta p_{t-k+1}+e_{t} .
$$

The correspondence between the ECM and the level VAR is given by

$$
\alpha \beta^{\prime}=-A(1) \text { and } \Gamma_{i}=-\sum_{i=j+1}^{k} A_{i} \text { for } j=1,2, \cdots, k-1 \text {. }
$$

The $E \beta^{\prime} p_{t}$ term in equation (1) captures systematic differences in the prices. It enters into the model in a nonlinear way with other parameters including $\alpha$.

$$
p_{t}=p_{0}+\psi\left(\sum_{s=1}^{t} e_{s}\right) l+\psi^{*}(L) e_{t}
$$

The common trends representation of the model (2) contains a single random walk term that is common to all prices. The increment $\psi e_{t}$ is the component of the price change that is permanently impounded into the security price and is presumably caused by new information. The variance of this term is $\psi \Omega \psi^{\prime}$. The proportion of this for market $j$ relative to the total variance is defined as market $j$ s information share:

$$
S_{j}=\frac{\psi_{j}^{2} \Omega_{j j}}{\psi \Omega \psi^{\prime}} .
$$

For the $\mathrm{n}$ market prices given by the factor structure,

$$
e_{t}=F z_{t} \text {. }
$$

where $z_{t}$ is an $(n \times 1)$ vector of random variables with $E z_{t}=0$ and $\operatorname{Var}\left(z_{t}\right)=I$, and $F$ is the Cholesky factorization of $\Omega$. The market share of the innovation variance attributable to $Z_{j}$ may be computed as ${ }^{9}$

$$
S_{j}=\frac{\left(\left[\psi^{F}\right]_{j}\right)^{2}}{\psi \Omega \psi^{\prime}},
$$

where $\left[\psi^{F}\right]_{j}$ is the $f^{\text {th }}$ element of the row matrix $\psi^{F}$.

\section{Empirical Results}

The results of this paper can be summarized as follows. Both the A- and H-share ${ }^{9}$ See Hasbrouck (1995) for more details. 
price series are non-stationary and co-integrated. In the multiple markets, A-shares contribute more in the intra-day price formation. This is consistent with the view of other studies (Demirgüç-Kunt \& Huizinga, 1995; Noronha et al., 1996), which contend that segmented markets are less efficient, especially for non-local investors, because of the information transmission. Our result supports the theoretical prediction of Nieuwerburgh and Veldkamp (2009) that the home market may have superior access to information.

Table 1 reports summary statistics of major variables of each pair of AH-share firms from January $1^{\text {st }}, 2006$ to December $31^{\text {st }}, 2006$. There are 17 pairs of firms that are listed on both the SSE/SZSE and the HKEx during 2006. "Daily Trades" corresponds to the average number of trades each day of 2006, which is equal to the total number of trades/number of trading days. "Trade Size (1)" corresponds to the trade size as measured by the number of shares and is equal to the average number of shares in each trade. "Trade Size (2)" corresponds to the trade size as measured by the turnover and is equal to the average turnover of each trade. "Daily Volume" equals the average number of shares that are traded in each day. "Daily Turnover" equals the average turnover that is traded in each day.

\subsection{The Co-Integration of Price Series Pairs}

Table 2 reports the result of the co-integration test of the two price series. We follow Chan et al. (2007) in testing co-integration by testing the stationarity of the price differential across the A-share and $\mathrm{H}$-share prices. We use an augmented Dickey and Fuller (1981) unit root test and the Dickey et al. (1984) limiting distribution with seasonal unit roots to account for seasonality. Table 2 reports the number of co-integrated pairs that are significant at the $5 \%$ level out of the 17 cross-listed pairs for the month in question. We find that the price series of 133 pairs out of 199 are cointegrated. The result suggests that the two price series are cointegrated.

\subsection{Price Discovery Analysis}

The cross-sectional averages of the daily coefficients of the efficient price for each firm month are reported in Table 3. The common factor is the implicit efficient price of the security, and it is defined as the random walk component of the price from the markets, which is a measure of the information intensity of the efficient price process. The comparative analysis results in Table 3 show that in each month the A-share always exhibits a one-order-of-magnitude higher coefficient for the common factor.

Information share estimates in each month are reported in Table 4. Means, medians, and standard deviations (across the day) are reported by month. The A-share price possesses by far, the dominant information share (greater than $70 \%$ of the mean and $97 \%$ of the median for all months) of the price discovery. The H-share price displays approximately a single-digit percentage. This supports our hypothesis that local investors dominate the price discovery process of 
Table 3. Coefficients of efficient price (common index price factor).

\begin{tabular}{ccc}
\hline Month & A-Share Price & H-Share Price \\
\hline Jan. & 0.8976 & 0.0361 \\
Feb. & 0.9214 & 0.0144 \\
Mar. & 0.8733 & 0.0779 \\
Apr. & 0.8943 & 0.0264 \\
May & 0.9179 & 0.0434 \\
Jun. & 0.9157 & 0.0189 \\
Jul. & 0.8804 & 0.0357 \\
Aug. & 0.8855 & 0.0687 \\
Sep. & 0.8627 & 0.0289 \\
Oct. & 0.8452 & 0.0646 \\
Nov. & 0.7751 & 0.0747 \\
Dec. & 0.8706 & 0.0427 \\
\hline
\end{tabular}

Note: This table reports the means of the daily coefficients of the efficient price for each company. These statistics are based on a vector error correction model of A-share and $\mathrm{H}$-share prices. We estimate the model on a daily basis from January $1^{\text {st }}, 2006$ to December $31^{\text {st }}, 2006$. The figures are averaged across firms for each month.

Table 4. Price-discovery information shares in AH shares.

\begin{tabular}{|c|c|c|c|c|}
\hline & A-share & H-share & A-share & H-share \\
\hline Month & $\begin{array}{c}\text { Information } \\
\text { Share Maximum }\end{array}$ & $\begin{array}{c}\text { Information } \\
\text { Share Maximum }\end{array}$ & $\begin{array}{c}\text { Information } \\
\text { Share Minimum }\end{array}$ & $\begin{array}{c}\text { Information } \\
\text { Share Minimum }\end{array}$ \\
\hline Jan. Mean & 0.73 & 0.09 & 0.70 & 0.04 \\
\hline Median & 0.99 & 0.04 & 0.92 & 0.01 \\
\hline Feb. Mean & 0.75 & 0.06 & 0.72 & 0.02 \\
\hline Median & 0.99 & 0.04 & 0.95 & 0.01 \\
\hline Mar. Mean & 0.75 & 0.06 & 0.73 & 0.02 \\
\hline Median & 0.99 & 0.04 & 0.94 & 0.01 \\
\hline Apr. Mean & 0.71 & 0.10 & 0.69 & 0.07 \\
\hline Median & 0.97 & 0.04 & 0.92 & 0.01 \\
\hline May Mean & 0.74 & 0.08 & 0.70 & 0.02 \\
\hline Median & 0.99 & 0.03 & 0.94 & 0.01 \\
\hline Jun. Mean & 0.72 & 0.11 & 0.68 & 0.04 \\
\hline Median & 0.98 & 0.05 & 0.89 & 0.01 \\
\hline Jul. Mean & 0.74 & 0.10 & 0.69 & 0.02 \\
\hline Median & 0.99 & 0.05 & 0.91 & 0.01 \\
\hline
\end{tabular}


Continued

\begin{tabular}{ccccc}
\hline Aug. Mean & 0.74 & 0.11 & 0.68 & 0.02 \\
Median & 0.98 & 0.06 & 0.90 & 0.01 \\
Sep. Mean & 0.73 & 0.09 & 0.69 & 0.03 \\
Median & 0.98 & 0.05 & 0.90 & 0.01 \\
Oct. Mean & 0.74 & 0.06 & 0.71 & 0.02 \\
Median & 0.99 & 0.04 & 0.95 & 0.01 \\
Nov. Mean & 0.73 & 0.07 & 0.70 & 0.03 \\
Median & 0.99 & 0.04 & 0.93 & 0.01 \\
Dec. Mean & 0.74 & 0.06 & 0.71 & 0.02 \\
Median & 0.98 & 0.03 & 0.94 & 0.01 \\
\hline
\end{tabular}

Note: This table reports the daily information share estimates in each month. These statistics are based on a firm's daily information share from Hasbrouck's (1995) vector error correction model with A-share and $\mathrm{H}$-share prices. We estimated the model using intraday data from each trading day from January $1^{\text {st }}, 2006$ to December $31^{\text {st }}, 2006$. The means and medians are averaged over the month in question and then across all firms during the month.

domestic stocks. The monthly results are quite consistent, with only small changes over time, and all of the results demonstrate that A-shares dominate $\mathrm{H}$-shares in the price discovery process. This is consistent with our hypothesis that non-local investors may deliberately choose not to obtain information about local Chinese companies and instead take a free ride on costly information acquisition by local investors. As such we observe the pattern of overinvestment in domestic stocks by local Chinese investors. Our results are also consistent with those of Qiao et al. (2008), who document that A-shares lead B-shares and that, in turn, B-shares lead H-shares.

\subsection{Liquidity Implications}

We next address the fundamental question: how is our price discovery result important to market liquidity? O'Hara (2003) mentions that liquidity and price discovery are related but are not the same. We are among the first to investigate the relation between a firm's information share and its market liquidity by comparing market liquidity in high and low information share subsamples. Following the literature on market liquidity (Hasbrouck, 2009; Goyenko et al., 2009), we employ three measures of market liquidity in Table 5: 1) the Amihud illiquidity ratio (Amihud, 2002), which is defined as the monthly average of the daily price change per dollar of the trading volume (all figures are multiplied by 106 for normalization (Amihud, 2002)); 2) the percentage of zero-return trading days (Lesmond et al., 1999); 3) the percentage of zero-return trading days with a positive volume (Lesmond et al., 1999). Information shares are computed following Hasbrouck (1995). Table 5 reports the means of stock market liquidity 
Table 5. Market liquidity and information share.

\begin{tabular}{ccccc}
\hline & & $\begin{array}{c}\text { Low Information } \\
\text { Share Firms }\end{array}$ & $\begin{array}{c}\text { High Information } \\
\text { Share Firms }\end{array}$ & t-statistics \\
\hline \multirow{2}{*}{ Amihud } & Obs. & 187 & 191 & $3.0766^{\star * *}$ \\
& Mean & 0.0152 & 0.0086 & \\
Zero-return days & Obs. & 168 & 169 & $-7.8664^{\star * *}$ \\
& Mean & 0.1759 & 0.3495 & \\
Zero-return days & Obs. & 168 & 151 & $-5.5841^{\star * *}$ \\
with positive volume & Mean & 0.1759 & 0.2719 & \\
\hline
\end{tabular}

Note: Significance at the $1 \%$ level is indicated by ${ }^{* * *}$.

for firms in high and low information share subsamples from January to December 2006. For each month, a firm belongs to the high (low) information share group if its information share is higher (lower) than the cross-sectional median for the month in question.

Satterthwaite t-statistics with unequal variances are estimated and reported in the last column. We find strong evidence that firms with high information share are more liquid. The average Amihud ratio is significantly smaller for firms with higher information share (e.g., the corresponding t-statistic equals 3.077), implying that, the price impact per dollar traded is lower. We find the average percent of zero-return days is significantly higher for firms with high information share. The result using the percentage of zero-return days with positive volume is also significant at $1 \%$. Overall our results suggest that firms with higher information share have more liquid stocks.

\section{Conclusion}

This paper provides evidence that the local market (i.e., China's A-share market) dominates the non-local market (i.e., the Hong Kong H-share market) in price discovery processes of dual-listed firms in Mainland China. The results support the theory of Nieuwerburgh and Veldkamp (2009) that home bias can be explained by their learning choice model when there is a comparative advantage in the local investors' information collection. Our results also support the finding by Veldkamp (2006) about the existence of markets of information and suggest that it may be more cost-efficient for local investors to collect information for local firms. This creates a comparative advantage for Mainland Chinese investors in obtaining information about dual-listed firms and trading their A-shares, which later creates an even larger information asymmetry. The dominance of the information shared in the local market suggests that local investors may choose to learn more than non-local investors for dual-listed stocks, thus amplifying local investors' information advantage. Our results further reconcile the mixed findings in the literature by providing a more direct test-we examine different contributions of local and non-local investors to the price discovery process, af- 
ter considering the differences in their portfolio returns. Our findings shed light on how markets aggregate information and may have important implications on portfolio diversification among A- and H-shares. Nevertheless, this paper may suffer from two drawbacks. For one thing, while this paper shows that home bias can be explained by the learning choice model, the information learning speed and proposition might be exaggerated. For another, we suggest that it may be more cost-efficient for local investors to collect local information in 2006 during China's stock market boom period. Such findings might be subject to sample limitations and specific institutional background. Hence, we recommend either introducing stock price overshooting or extending sample dimensions to facilitate future studies on similar topics.

\section{Conflicts of Interest}

The authors declare no conflicts of interest regarding the publication of this paper.

\section{References}

Ahearne, A., Griever, W., \& Warnock, F. (2004). Information Costs and Home Bias: An Analysis of U.S. Holdings of Foreign Equities. Journal of International Economics, 62, 313-336. https://doi.org/10.1016/S0022-1996(03)00015-1

Amihud, Y. (2002). Illiquidity and Stock Returns: Cross-Section and Time-Series Effects. Journal of Financial Markets, 5, 31-56. https://doi.org/10.1016/S1386-4181(01)00024-6

Chan, K. (1992). A Further Analysis of the Lead-Lag Relationship between the Cash Market and Stock Index Futures Market. Review of Financial Studies, 5, 123-152.

https://doi.org/10.1093/rfs/5.1.123

Chan, K., Menkveld, A., \& Yang Z. (2008). Information Asymmetry and Asset Prices: Evidence from the China Foreign Share Discount. Journal of Finance, 63, 159-196. https://doi.org/10.1111/j.1540-6261.2008.01313.x

Chan, K., Menkveld, A., \& Yang, Z. (2007). The Informativeness of Domestic and Foreign Investors' Stock Trades: Evidence from the Perfectly Segmented Chinese Market. Journal of Financial Markets, 10, 391-415. https://doi.org/10.1016/j.finmar.2007.07.001

Chui, A., \& Kwok, C. (1998). Cross-Autocorrelation between A Shares and B Shares in the Chinese Stock Market. Journal of Financial Research, 21, 333-353. https://doi.org/10.1111/j.1475-6803.1998.tb00689.x

Dahlquist, M., Pinkowitz, L., Stulz, R., \& Williamson, R. (2003). Corporate Governance and the Home Bias. Journal of Financial and Quantitative Analysis, 38, 87-110. https://doi.org/10.2307/4126765

Demirgüç-Kunt, A., \& Huizinga, H. (1995). Barriers to Portfolio Investments in Emerging Stock Markets. Journal of Development Economics, 47, 355-374. https://doi.org/10.1016/0304-3878(95)00017-K

Dickey, D. A., \& Fuller, W. A. (1981). Likelihood Ratio Statistics for Autoregressive Time Series with a Unit Root. Econometrica, 49, 1057-1072. https://doi.org/10.2307/1912517

Dickey, D. A., Hasza, D. P., \& Fuller, W. A. (1984). Testing for Unit Roots in Seasonal Time Series. Journal of the American Statistical Association, 79, 355-367. https://doi.org/10.1080/01621459.1984.10478057 
Eun, C., \& Sabherwal, S. (2003). Cross-Border Listing and Price Discovery: Evidence from U.S.-Listed Canadian Stocks. Journal of Finance, 58, 549-575. https://doi.org/10.1111/1540-6261.00537

Fidora M., Fratzscher, M., \& Thimann, C. (2007). Home Bias in Global Bond and Equity Markets: The Role of Real Exchange Rate Volatility. Journal of International Money and Finance, 26, 631-655. https://doi.org/10.1016/j.jimonfin.2007.03.002

Glassman, D., \& Riddick, L. (2001). What Causes Home Asset Bias and How Should It Be Measured? Journal of Empirical Finance, 8, 35-54. https://doi.org/10.1016/S0927-5398(00)00026-8

Goyenko, R., Holden, C. W., \& Trzcinka, C. (2009). Do Liquidity Measures Measure Liquidity? Journal of Financial Economics, 92, 153-181. https://doi.org/10.1016/j.jfineco.2008.06.002

Grinblatt, M., \& Keloharju, M. (2000). The Investment Behavior and Performance of Various Investor Types: A Study of Finland's Unique Data Set. Journal of Financial Economics, 55, 43-67. https://doi.org/10.1016/S0304-405X(99)00044-6

Hameed, W. (1997). Time-Varying Factors and Cross-Autocorrelations in Short-Horizon Stock Returns. Journal of Financial Research, 20, 435-458. https://doi.org/10.1111/j.1475-6803.1997.tb00259.x

Harris, F., McInish, T., Shoesmith, G., \& Wood, R. (1995). Cointegration, Error Correction and Price Discovery on Informationally Linked Security Markets. Journal of Financial and Quantitative Analysis, 30, 563-579. https://doi.org/10.2307/2331277

Hasbrouck, J. (1995). One Security, Many Markets: Determining the Contributions to Price Discovery. Journal of Finance, 50, 1175-1199. https://doi.org/10.1111/j.1540-6261.1995.tb04054.x

Hasbrouck, J. (2009). Trading Costs and Returns for U.S. Equities: Estimating Effective Costs from Daily Data. Journal of Finance, 64, 1445-1477. https://doi.org/10.1111/j.1540-6261.2009.01469.x

Ivković, Z., \& Weisbenner, S. (2005). Local Does as Local Is: Information Content of the Geography of Individual Investors' Common Stock Investments. Journal of Finance, 60, 267-306. https://doi.org/10.1111/j.1540-6261.2005.00730.x

Lesmond, D. A., Ogden, J. P., \& Trzcinka, C. A. (1999). A New Estimate of Transaction Costs. Review of Financial Studies, 12, 1113-1141. https://doi.org/10.1093/rfs/12.5.1113

Li, K., Sarkar, A., \& Wang, Z. (2003). Diversification Benefits of Emerging Markets Subject to Portfolio Constraints. Journal of Empirical Finance, 10, 57-80. https://doi.org/10.1016/S0927-5398(02)00027-0

Massa, M., \& Simonov, A. (2006). Hedging, Familiarity, and Portfolio Choice. Review of Financial Studies, 19, 633-685. https://doi.org/10.1093/rfs/hhj013

Mech, T. (1993). Portfolio Return Autocorrelation. Journal of Financial Economics, 34, 307-344. https://doi.org/10.1016/0304-405X(93)90030-F

Nieuwerburgh, S., \& Veldkamp, L. (2009). Information Immobility and the Home Bias Puzzle. Journal of Finance, 64, 1187-1215. https://doi.org/10.1111/j.1540-6261.2009.01462.x

Noronha, G., Sarin, A., \& Saudagaran, S. (1996). Testing for Micro-Structure Effects of International Dual Listing. Journal of Banking and Finance, 20, 965-983. https://doi.org/10.1016/0378-4266(95)00038-0

O’Hara, M. (2003). Presidential Address: Liquidity and Price Discovery. Journal of Finance, 58, 1335-1354. https://doi.org/10.1111/1540-6261.00569 
Qiao, Z., Li, Y., \& Wong, W. K. (2008). Policy Change and Lead-Lag Relations among China's Segmented Stock Markets. Journal of Multinational Financial Management, 18, 276-289. https://doi.org/10.1016/j.mulfin.2007.11.001

Seasholes, M. S., \& Zhu, N. (2010). Individual Investors and Local Bias. Journal of Finance, 65, 1987-2010. https://doi.org/10.1111/j.1540-6261.2010.01600.x

Smith, K., \& Sofianos, G. (1997). The Impact of an NYSE Listing on the Global Trading of Non-U.S. Stocks. Working Paper No. 97-02, New York Stock Exchange.

Stoll, H., \& Whaley, R. (1990). Stock Market Structure and Volatility. Review of Financial Studies, 3, 37-71. https://doi.org/10.1093/rfs/3.1.37

Tesar, L., \& Werner, I. (1995). Home Bias and High Turnover. Journal of International Money and Finance, 14, 467-492. https://doi.org/10.1016/0261-5606(95)00023-8

Veldkamp, L. (2006). Information Markets and the Comovement of Asset Prices. Review of Economic Studies, 73, 823-845. https://doi.org/10.1111/j.1467-937X.2006.00397.x

Wong, S., Tan, D., \& Tian, Y. (2009). Informed Trading and Liquidity in the Shanghai Stock Exchange. International Review of Financial Analysis, 18, 66-73.

https://doi.org/10.1016/j.irfa.2008.11.002 